\title{
Potential of Trichosporon asahii against Alternaria sp. and mechanisms of action
}

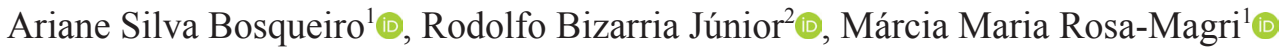

${ }^{1}$ Universidade Federal de São Carlos, Centro de Ciências Agrárias, Departamento de Recursos Naturais e Proteção Ambiental, Rodovia Anhanguera, km 174, CEP:13600-970, Araras/SP, Brasil. ${ }^{2}$ Universidade Estadual Paulista Julio de Mesquita Filho, Instituto de Biociências, Departamento de Bioquímica e Microbiologia, Av. 24-A, n.1515, Bela Vista, CEP: 13506-900, Rio Claro/SP, Brasil.

Corresponding author: Márcia Maria Rosa Magri (mrciarosa@yahoo.com.br)

Data de chegada: 06/03/2019. Aceito para publicação em: 19/12/2019.

$10.1590 / 0100-5405 / 220861$

\section{ABSTRACT}

Bosqueiro, A.S.B.; Bizarria Júnior, R.; Rosa-Magri, M.M. Potential of Trichosporon asahii against Alternaria sp. and mechanisms of action. Summa Phytopathologica, v.46, n.1, p.20-25, 2020.

Alternaria sp. is a fungus that causes rot in several crops, causing damage to the agricultural production chain. Biological control agents constitute an alternative to reduce the use of pesticides in the crops, a social demand for modern agriculture. The aim of the present study is to demonstrate the antagonistic effect of the yeast Trichosporon asahii (3S44) on the mycelial development of Alternaria sp. and some in vitro mechanisms of action. Trichosporon asahii showed antagonistic activity towards Alternaria sp., presenting mycelial inhibition (57.47\%). The assays indicated production of volatile organic compounds (VOCs), competition for nutrients, biofilm formation, production of killer toxins and $\beta-1,3-$ glucanase as mechanisms of action of $T$. asahii. Collectively, our results showed the potential of T. asahii to control the mycelial development of Alternaria sp. and some mechanisms of action of this yeast for future biotechnological studies.

Keywords: Antagonism; yeast; biological control; mechanisms of action

\section{RESUMO}

Bosqueiro, A.S.B.; Bizarria Júnior, R.; Rosa-Magri, M.M. Trichosporon asahii contra Alternaria sp. e mecanismos de ação. Summa Phytopathologica, v.46, n.1, p.20-25, 2020.

Alternaria sp. é um fungo que causa podridão em diferentes culturas agrícolas, causando danos a cadeia de produção. Agentes de controle biológico são uma alternativa para reduzir o uso de agrotóxicos nas lavouras, uma demanda social para a agricultura moderna. O objetivo deste trabalho é demonstrar o efeito antagônico da levedura Trichosporon asahii (3S44) no desenvolvimento micelial de Alternaria sp. e alguns dos mecanismos de ação in vitro. Trichosporon asahii apresenta atividade antagônica frente
Alternaria sp., com inibição micelial (57,47\%). Os ensaios indicaram a produção de compostos orgânicos voláteis (COVs), competição por nutrientes, formação de biofilme, produção de toxina killer e $\beta$-1,3-glucanase como mecanismos de ação de $T$. asahii. Coletivamente, os resultados demonstraram o potencial de T. asahii no controle do desenvolvimento micelial de Alternaria sp. e mecanismos de ação da levedura, para futuros estudos biotecnológicos.

Palavras-chave: Antagonismo, Levedura, Controle biológico, Mecanismos de ação

Some Alternaria species are pathogens of plants of agricultural importance, causing economic impact on several crops such as cereals, ornamental plants, broccoli, cauliflowers, potatoes, carrots, tomatoes, citruses and apples (24). Besides, the mycotoxins produced by Alternaria are toxic to humans and animals (18).

Synthetic fungicides are widely used in traditional agriculture to control crop diseases. Meanwhile, agroecological practices have been proposed as an alternative for pest management (27). Biological control with microorganisms has been one of the most studied processes (23), leading to the description of different yeast species with potential to control phytopathogenic fungi $(10,19,21)$.

Microorganisms can use several mechanisms to antagonize fungi that cause crop damage, such as competition for nutrients and space, production of volatile compounds $(19,21)$, production of killer toxins and hydrolytic enzymes (19), and formation of biofilm (5).

Although there are several reports of yeasts as potential biological control agents, few studies have been carried out on Alternaria control
$(20,30)$. Here, we demonstrated inhibition of Alternaria mycelial growth by Trichosporon asahii (strain 3S44) and identified some mechanisms of action for future development of technologies and sustainable practices in modern agriculture.

\section{MATERIAL AND METHODS}

\section{Preservation and maintenance of cultures}

The studied strain of T. asahii (3S44) was obtained from maize rhizosphere (22). The yeast was selected from the Federal University of São Carlos, Araras, São Paulo State, Brazil (22²1'25's; 47²3'03”W). The strain was kept in YEPD (Yeast Extract Peptone Dextrose $\mathrm{g} \mathrm{L}^{-1}$ : 10 yeast extract, 20 peptone, 20 glucose, 20 agar, $\mathrm{pH}=6.5 \pm 0.2)$ in slant culture with $0.5 \%$ glycerol.

Alternaria sp. was isolated from tomatoes showing rot symptoms. Then, conidia of the obtained strain were inoculated in healthy tomatoes 
for pathogenicity test. The culture was kept in PDA (Potato Dextrose Agar, Himedia ${ }^{\circledR}, \mathrm{pH}=5.6 \pm 0.2$ ). For assays, conidia were removed from 14-day-old cultures with a sterile instrument, suspended in $0.05 \%$ $(\mathrm{v} / \mathrm{v})$ Tween 20 , and the concentration was adjusted to $10^{5}$ conidia $\mathrm{mL}^{-1}$ in a Neubauer chamber.

\section{Pairwise culture assays}

To confirm the antagonism of T. asahii towards Alternaria sp., dual-culture assays were performed in PDA plates supplemented with tetracycline and chloramphenicol $(0.01 \%)$. Mycelial fragments of Alternaria sp. (6-mm diameter) were placed $1.5 \mathrm{~cm}$ apart from the edge of a Petri dish. Trichosporon asahii was streaked $3 \mathrm{~cm}$ apart on the opposite side. Control group consisted of a culture of Alternaria sp. grown alone without the yeast. Assays were conducted with six plates incubated at $28^{\circ} \mathrm{C}$ for seven days. Alternaria sp. growth $\left(\mathrm{cm}^{2}\right)$ was measured in the absence and presence of the yeast with the software ImageJ v.1.4.3.67.

\section{Production of volatile organic compounds (VOCs)}

The yeast was evaluated for production of VOCs as a mechanism of action towards Alternaria sp. with overlapping plates, according to Parafati et al. (19) with modifications. Yeast cells $\left(100 \mu \mathrm{L}\right.$ of $10^{8}$ cells $\mathrm{mL}^{-1}$ ) were spread on the surface of a Petri plate containing PDA. The same procedure was conducted for Alternaria sp. (100 of $\mu \mathrm{L} 10^{5}$ conidia $\mathrm{mL}^{-1}$ ). Plates were overlapped face to face (the yeast on the top) and sealed with parafilm ${ }^{\circledR}$. Control group was prepared only with Alternaria sp., and a sterile PDA plate was used to overlap. The assay was conducted for 3 days at $28^{\circ} \mathrm{C}$, and Alternaria sp. growth $\left(\mathrm{cm}^{2}\right)$ was measured as previously described.

\section{Killer activity}

The yeast was evaluated for production of killer toxins towards a sensitive strain of Saccharomyces cerevisiae (NCYC 1006), according to Ceccato-Antonini et al. (4) with modifications. Yeast cells $(100 \mu \mathrm{L}$ of $10^{5}$ cells $\mathrm{mL}^{-1}$ ) were spread on the surface of a Petri plate containing YEPD supplemented with methylene blue (citrate-phosphate buffer, final $\mathrm{pH}=4.5$ ). $T$. asahii was seeded on the medium surface with a sterile instrument. Plates were incubated at $28^{\circ} \mathrm{C}$ for five days and daily observed. The strain was considered a killer toxin producer when a growth inhibition halo with an adjacent blue zone, due to the death of sensitive yeasts, was observed. The assay was conducted with five plates.

\section{Nutrient competition}

The effect of nutrient competition by $T$. asahii on conidial germination of Alternaria sp. was evaluated according to Zhang et al. (29) with modifications. Test tubes containing $4.8 \mathrm{~mL}$ sterile tomato juice medium (1:4 tomato juice diluted in sterile water) were inoculated with $100 \mu \mathrm{L}$ of $10^{8}$ cells $\mathrm{mL}^{-1}$ yeast and $100 \mu \mathrm{L}$ of $10^{5}$ conidia $\mathrm{mL}^{-1}$ Alternaria sp. Tomato juice medium was supplemented with dextrose $(0.5,1.0$, and $1.5 \%)$ and $\mathrm{FeCl}_{3} .7 \mathrm{H}_{2} \mathrm{O}(0.1,0.5,1.0 \mathrm{mM})$. Tubes were incubated at $25^{\circ} \mathrm{C}, 200 \mathrm{rpm}$, for 20 hours. Afterwards, 35 conidia were randomly selected and the presence of germination tube was measured. Control group consisted in the isolated growth of Alternaria with 100 $\mu \mathrm{L}$ sterile water to replace the yeast cells. Three tubes were used for each treatment, and conidial germination was expressed as percentage.

\section{Biofilm formation}

The yeast was evaluated for its capacity to form biofilm according to Vero et al. (26) with modifications. The yeast was previously grown for 24 hours at $25^{\circ} \mathrm{C}$ in YEPD. Microtubes of $2 \mathrm{~mL}$ containing 900 $\mathrm{mL}$ YEPD were inoculated with $100 \mu \mathrm{L}$ yeast cells $\left(10^{8}\right.$ cell $\left.\mathrm{mL}^{-1}\right)$ and incubated at $25^{\circ} \mathrm{C}$ for 2 days at $75 \mathrm{rpm}$. Control was prepared without the yeast inoculum. Afterwards, the suspension in microtubes were removed by single inversion, washed three times with sterile water and dried at room temperature. The adherent biofilm layer was stained with crystal violet solution at $1 \%(\mathrm{w} / \mathrm{v})$ for 20 minutes, and the microtubes were rinsed 3 times with sterile water followed by a drying step. Dye was eluted from each microtube with $1 \mathrm{~mL} 95 \%$ ethanol. Absorbance was measured $(620 \mathrm{~nm})$. Biofilm formation was considered positive when the absorbance mean was higher than that of the negative control plus three standard errors. The assay was conducted in six wells and repeated twice.

\section{Production of hydrolytic enzymes}

The yeast strain was evaluated for the production of chitinase and $\beta$-1,3-glucanase. For chitinase production, colloidal chitin was used as substrate and prepared according to Liu et al. (13) with modifications. Chitinase activity was determined by measuring the release of $\mathrm{N}$-acetylglucosamine based on the ADNS method, according to Nally et al. (16). Yeasts were inoculated $\left(100 \mu \mathrm{L}\right.$ of $10^{8}$ cells $\left.\mathrm{mL}^{-1}\right)$ in $50 \mathrm{~mL}$ falcon tubes containing $15 \mathrm{~mL} \mathrm{YNB}$ (Yeast nitrogen base, $6.7 \mathrm{~g} \mathrm{~L}^{-1}$ ), 0.1 $\mathrm{M}$ sodium acetate buffer, $\mathrm{pH}$ 5.5, and colloidal chitin $\left(10 \mathrm{~g} \mathrm{~L}^{-1}\right)$. Colloidal chitin concentration was determined by drying the sample at $60^{\circ} \mathrm{C}$ up to constant dry weight (3). Tubes were incubated at $160 \mathrm{rpm}, 25^{\circ} \mathrm{C}$, for 60 hours. Every 12 hours, $500 \mu \mathrm{L}$ were sampled and centrifuged at 10000 $\mathrm{g}$ for 6 minutes. An amount of $250 \mu \mathrm{L}$ cell-free supernatant was mixed with $250 \mu \mathrm{L} 0.1 \mathrm{M}$ sodium acetate buffer supplemented with $10 \mathrm{~g} \mathrm{~L}^{-1}$ colloidal chitin (final $\mathrm{pH}=5.5$ ). This mixture was incubated in water bath at $37^{\circ} \mathrm{C}$ for 1 hour. After incubation, samples were supplemented with $500 \mu \mathrm{L}$ of 3,5-dinitrosalicylic acid (ADNS) and immersed in water bath at $100^{\circ} \mathrm{C}$ for 10 minutes. $\mathrm{N}$-acetylglucosamine was quantified in spectrophotometer at $540 \mathrm{~nm}$ using standard curve. In the last sample (60 hours), cells of yeasts were harvested, and the dry weight was defined. The assay was carried out three times and the control group did not contain the yeast.

For $\beta$-1,3-glucanase production, the assay was conducted according to Nally et al. (16) with modifications. Laminarin was used as substrate. The yeast was inoculated $\left(100 \mu \mathrm{L}\right.$ of $10^{8}$ cells $\left.\mathrm{mL}^{-1}\right)$ in $50 \mathrm{~mL}$ falcon tubes containing $15 \mathrm{~mL}$ YNB (Yeast nitrogen base, $6.7 \mathrm{~g} \mathrm{~L}^{-1}$ ), $0.1 \mathrm{M}$ sodium acetate buffer at $\mathrm{pH} 5.5$, and laminarin $\left(2 \mathrm{~g} \mathrm{~L}^{-1}\right)$. Tubes were incubated at $160 \mathrm{rpm}, 25^{\circ} \mathrm{C}$, for 60 hours. Every 12 hours, $500 \mu \mathrm{L}$ were sampled and centrifuged at $10000 \mathrm{~g}$ for 6 minutes. An amount of 250 $\mu \mathrm{L}$ cell-free supernatant was mixed with $250 \mu \mathrm{L} 0.1 \mathrm{M}$ sodium acetate buffer supplemented with $2 \mathrm{~g} \mathrm{~L}^{-1}$ laminarin (final $\mathrm{pH}=5.5$ ). This mixture was incubated in water bath at $45^{\circ} \mathrm{C}$ for 30 minutes. After incubation, samples were supplemented with $500 \mu \mathrm{L}$ of 3,5-dinitrosalicylic acid (ADNS) and immersed in water bath at $100^{\circ} \mathrm{C}$ for 10 minutes. Dextrose was quantified in spectrophotometer at $540 \mathrm{~nm}$ using standard curve. In the last sample (60 hours) cells of yeasts were harvested, and the dry weight was defined. The assay was carried out three times and the control group did not contain the yeast.

\section{Statistical analyses}

Data from pairwise culture were evaluated based on Two-sample T-test with an alpha threshold of 0.05. Data from VOCs and biofilm tests were analyzed according to Mann-Whitney $U$ test with an alpha threshold of 0.05. Kruskal-Wallis analysis and Student-Newman-Keuls 
test with an alpha threshold of 0.05 were used for the nutrient competition assay. When assumptions of normality and homogeneity were required, the data were previously verified according to Shapiro-wilk and Bartlett tests, respectively. The analyses were performed in $\mathrm{R}$ v.3.3.3.

\section{RESULTS AND DISCUSSION}

\section{Inhibition of Alternaria sp. by T. asahii}

In the presence of $T$. asahii, the mycelial area of Alternaria sp. was inhibited to $22.3 \mathrm{~cm}^{2}$, while in the absence of the yeast (control) the mycelial area was $52.3 \mathrm{~cm}^{2}(57.47 \%$ inhibition; Figure 1). Pairwise test can provide information about the antagonistic potential of strains towards phytopathogenic fungi, and some studies have also provided information about the potential of T. asahii towards phytopathogenic fungi (9).

\section{Production of volatile organic compounds (VOCs)}

The mycelial area of Alternaria sp. was inhibited in the presence of VOCs produced by $T$. asahii (Figure 2). In the presence of yeast compounds, the mycelial area of Alternaria was $36.6 \mathrm{~cm}^{2}$, compared to control which had $52.5 \mathrm{~cm}^{2}$ (30.2\% inhibition). Production of VOCs by microorganisms can be an important tool for post-harvest control, since the microorganism does not get in contact with the fruit or the vegetable (17), as well as for the biofumigation technique, especially for food that need to be stored (1). Production of VOCs by yeasts has been widely reported $(6,19,25)$, and future studies may be conducted for the characterization of compounds released by this strain.

\section{Killer activity}

T. asahii (3S44) showed positive production of killer toxins and blue halo formation on sensitive yeasts. Killer activity means production of toxins that are lethal to some microorganisms of the same or different species (15), an important trait of some yeasts (14). Production of killer toxins by $T$. asahii was also reported by another study (7), evidencing control activity against Cryptococcus neoformans, which has medical importance. Future studies must be conducted to purify and use these toxins towards microorganisms of interest.

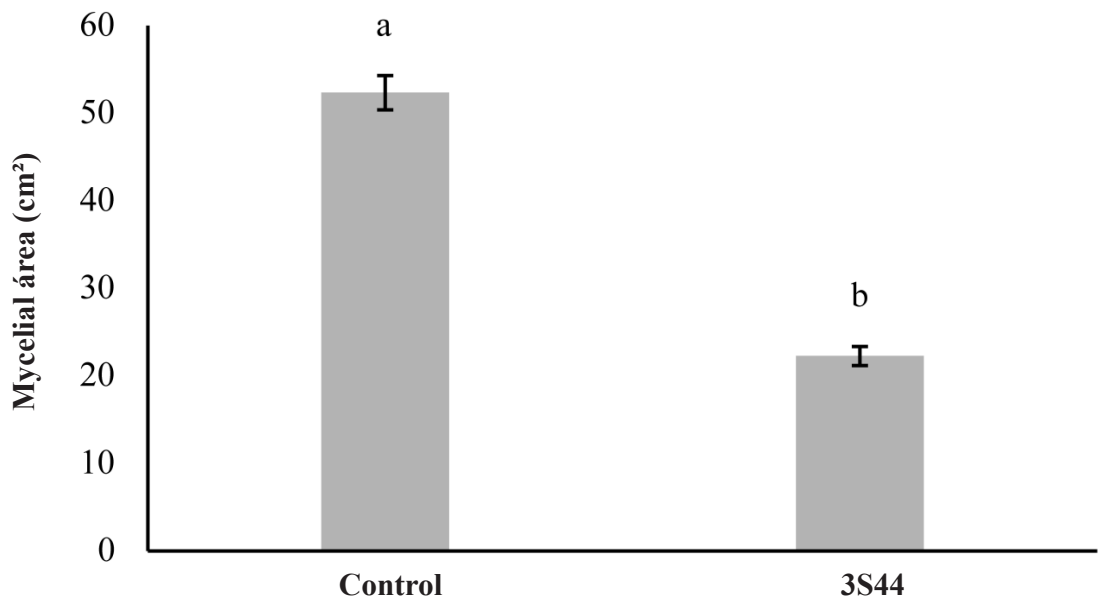

Figure 1. Mycelial area in dual culture assays. Alternaria sp. growth on PDA after seven days at $28^{\circ} \mathrm{C}$ in the absence (Control) and presence of $T$. asahii (3S44). Means $( \pm \mathrm{SE})$ with different letters on the top of bars indicate significant differences according to Two-sample T-test $(P=0.000)$.

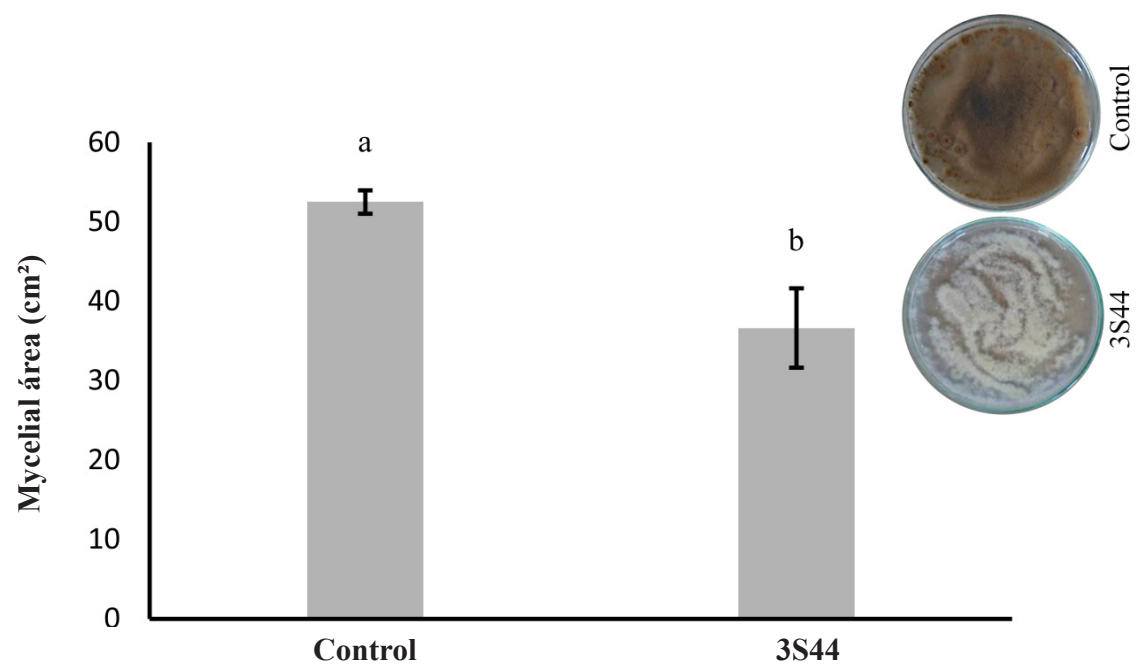

Figure 2. Mycelial area in VOCs assays. Alternaria sp. growth on overlapping plates after three days at $28^{\circ} \mathrm{C}$ in the absence $(\mathrm{Control})$ and presence of $T$. asahii (3S44). Means ( $\pm \mathrm{SE})$ with different letters on the top of bars indicate significant differences according to Mann-Whitney $U$ test $(P=$ 0.026). Plates on the top indicate the growth pattern of Alternaria sp. in the absence (Control) and presence (3S44) of volatile organic compounds. 


\section{Nutrient competition}

Competition for nutrients is one of the most important mechanisms reported for yeasts $(8,17,23)$. Our results indicate a decrease in conidial germination in the presence of T. asahii (3S44). Considering dextrose competition, lower germination percentage was observed for Alternaria conidia in the presence of T. asahii. Conidial germination was most inhibited at $0.5 \%$ glucose concentration: with $43.8 \%$ of conidia germinated in the presence of the yeast, when compared to $91.4 \%$ in the absence (Figure 3). Increasing glucose concentration had a positive impact on conidial germination, which also increased (Figure 3). Lower germination was observed at different concentrations of $\mathrm{Fe}^{3+}$. The lowest values of conidial germination were observed for the concentration of $0.5 \mathrm{mM}(46.7 \%)$ in the presence of the yeast, when compared to 0.1 and $1.0 \mathrm{mM}$, which reached 58.1 and $75.2 \%$ of germinated conidia, respectively (Figure 4).

Yeasts can use a variety of carbohydrates, including disaccharides and monosaccharides (29). Inhibition of conidial germination in the presence of different concentrations of dextrose may be related to the uptake of such compounds and the production of inhibitory soluble metabolites in an interference competition (28). On the other hand, iron plays a different role as a cofactor in metabolic pathways (11). One of the strategies used by yeasts for iron competition is the production of siderophores, iron-chelating compounds secreted to form a stable complex with iron ions, making them unavailable to other microorganisms, such as phytophatogenic fungi, which have their growth, germination and pathogenesis impaired (8).

\section{Biofilm formation}

T. asahii showed biofilm formation under the analyzed conditions (Table 1). There were increasing absorbance levels after alcohol elution, which indicates biofilm formation by the strain. Such production could be considered an antagonistic mechanism of yeasts to control phytopathogenic fungi (23), and biofilm formation can contribute to the biocontrol activity by yeasts (12). Biofilm formation may also increase the resistance to oxidative stress, an important requirement for yeasts to remain viable and maintain the antagonistic activity (5).

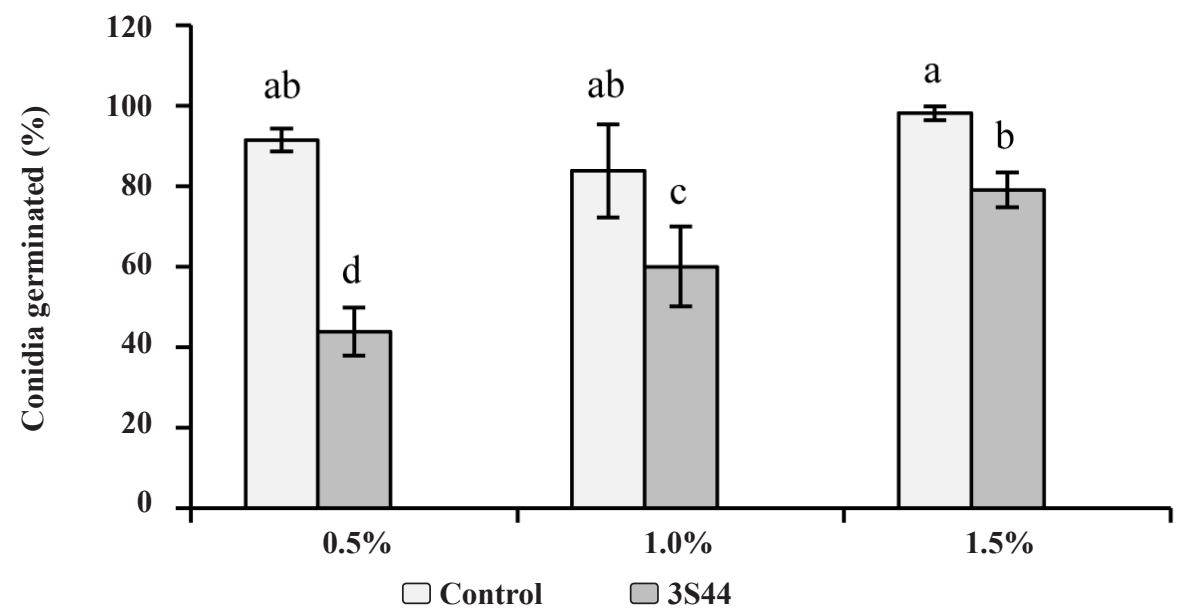

Figure 3. Percentage of germinated conidia of Alternaria sp. in the absence (Control) and presence of T. asahii (3S44) towards different dextrose concentrations. Means $( \pm \mathrm{SE})$ with different letters on the top of bars indicate significant differences according to Kruskal-Wallis analysis $(P=$ 0.008 ) followed by Student-Newman-Keuls test with an alpha threshold of 0.05 .

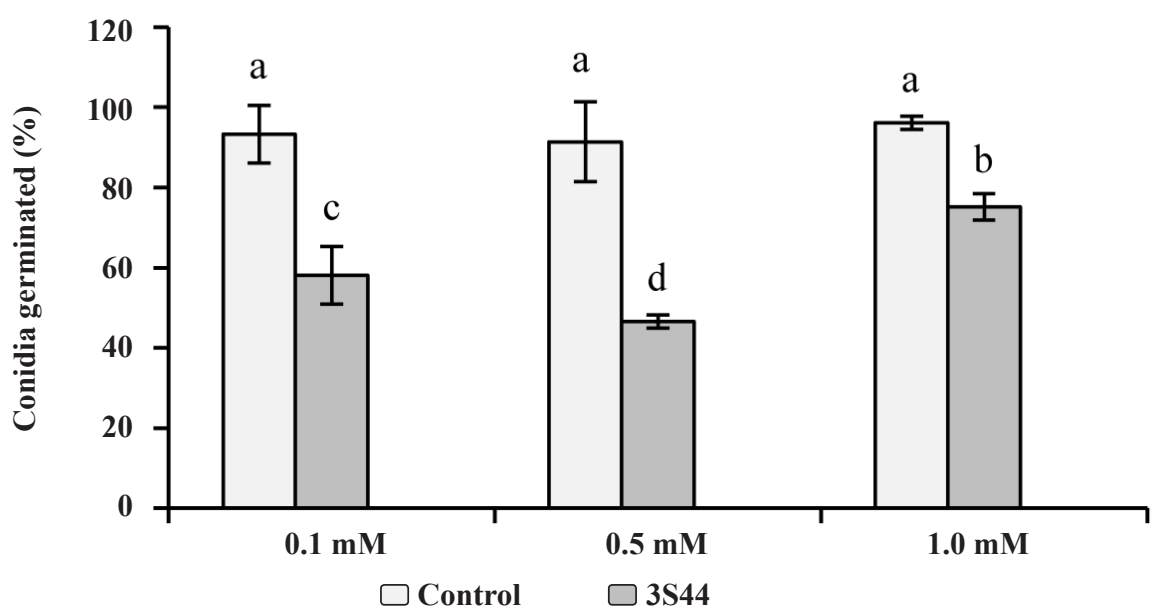

Figure 4. Percentage of germinated conidia of Alternaria sp. in the absence (Control) and presence of T. asahii (3S44) towards different Fe ${ }^{3+}$ ion concentrations. Means $( \pm \mathrm{SE})$ with different letters on the top of bars indicate significant differences according to Kruskal-Wallis analysis $(P=$ 0.010 ) followed by Student-Newman-Keuls test with an alpha threshold of 0.05 . 


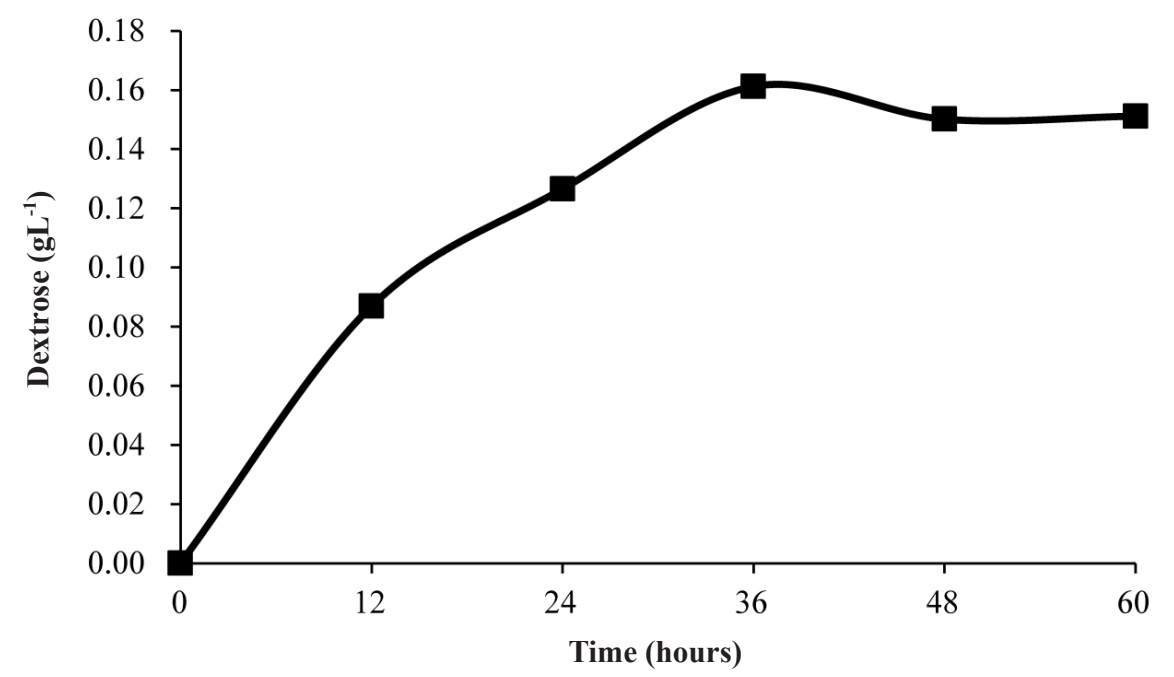

Figure 5. Dextrose concentration over time as a result of $\beta$-1,3-glucanase activity produced by T. asahii (3S44). Dextrose was detected in a spectrophotometer $(540 \mathrm{~nm})$ and quantified with a standard curve.

Table 1. Biofilm formation of T. asahii (3S44).

\begin{tabular}{cc} 
Treatment & $\mathbf{A}^{\mathbf{6 2 0}}$ (Mean + Standard error) \\
T. asahii (3S44) & $0.421 \pm 0.061^{\mathrm{a}}$ \\
Control & $0.031 \pm 0.003^{\mathrm{b}}$ \\
\hline
\end{tabular}

Figures indicate the Mean $( \pm \mathrm{SE})$ of absorbance and different letters indicate significant differences according to Mann-Whitney $U$ test $(P=0.000)$.

\section{Production of hydrolytic enzymes}

The evaluated yeast showed production of $\beta$-1,3-glucanase, measured by the release of reduced sugar, as a result of enzymatic activity. After 60 hours of culture, the yeast was capable of producing $\beta$-1,3-glucanase, at dextrose concentrations of $0.15 \mathrm{~g} \mathrm{~L}^{-1}$ and $0.31 \mathrm{~g}$ $\mathrm{L}^{-1}$ for dry cell weight ( $0.48 \mathrm{~g}$ dextrose per $\mathrm{g}$ dry weight; Figure 5$)$. Meanwhile, for chitinase production, no $\mathrm{N}$-acetylglucosamine was detected as a product of enzymatic activity. Control group did not show any production, as expected.

Production of extracellular enzymes has been reported as an important trait for the biological control of phytopathogenic fungi (23). Since the cell wall of fungi consists of glycoproteins and polysaccharides, manly glucan and chitin (2), the breakdown of such structures requires the use of different enzymes by antagonistic microorganisms, which may cause deformities, cytological damages, lysis of mycelium, and changes on membrane permeability (8). Ferraz et al. (10) evaluated strains of Rhodotorula minuta and Saccharomyces cerevisiae for hydrolytic enzymes and found that one of the main mechanisms could be related to the production of $\beta$-1,3-glucanase, yielding $0.004 \mathrm{~g} \mathrm{~L}^{-1}$ and $0.039 \mathrm{~g} \mathrm{~L}^{-1}$ dextrose for $R$. minuta and $S$. cerevisiae, respectively, after 24-hour incubation. Our production was higher than that reported by such authors.

Our results indicate the potential of T. asahii towards Alternaria sp. and some of its mechanisms that can be used for future biotechnological investigations. The yeast showed positive activity for different mechanisms of action, such as production of VOCs, killer activity, biofilm formation, production of $\beta 1,3$-glucanase and competition for nutrients, which harm conidial germination of Alternaria sp. Future studies must be conducted to provide information about the use of this yeast in applied sciences, such as in biological control.

\section{ACKNOWLEDGMENTS}

The authors thank FAPESP (The São Paulo Research Foundation - 2016 / 02541-7) and CAPES (Coordination for the Improvement of Higher Education Personnel) - Financial Code 001, for the financial grant to the first author.

\section{REFERENCES}

1. Arrarte, E.; Garmendia, G.; Rossini, C.; Wisniewski, M.; Vero, S. Volatile organic compounds produced by Antarctic strains of Candida sake play a role in the control of postharvest pathogens of apples. Biological Control, Atlanta, v. 109, p. 14-20, 2017.

2. Bowman, S. M.; Free, S. J. The structure and synthesis of the fungal cell wall. Bioessays, Hoboken, v. 28, n. 8, p. 799-808, 2006.

3. Cattelan, A. J. Métodos qualitativos para determinação de características bioquímicas e fisiológicas associadas com bactérias promotoras de crescimento vegetal. Londrina: Embrapa Soja, 1999. 36 p. Available in: $<$ https://www.infoteca.cnptia.embrapa.br/bitstream/doc/461542/1/doc139. pdf>. Access: 01 Feb. 2019.

4. Ceccato-Antonini, S. R.; Tosta, C. D.; Silva, A. C. Determination of yeast killer activity in fermenting sugarcane juice using selected ethanol-making strains. Brazilian Archives of Biology and Technology, Curitiba, v. 47, n. 1, p. 13-23, 2004.

5. Chi, M.; Li, G.; Liu, Y.; Liu, G.; Li, M.; Zhang, X.; Sun, Z.; Sui, Y.; Liu, J. Increase in antioxidant enzyme activity, stress tolerance and biocontrol efficacy of Pichia kudriavzevii with the transition from a yeast-like to biofilm morphology. Biological Control, Amsterdam, v. 90, p. 113-119, 2015.

6. Di Francesco, A.; Ugolini, L.; Lazzeri, L.; Mari, M. Production of volatile organic compounds by Aureobasidium pullulans as a potential mechanism of action against postharvest fruit pathogens. Biological Control, Atlanta, v. 81, p. 8-14, 2015.

7. Dubash, T.; Gupta, S.; Prakash, P.Y.; Bairy, I. Isolation of yeasts from various food products and detection of killer toxin activity in vitro. Journal of Scientific Research, Bangladesh, v. 2, n. 2, p. 407-411, 2010.

8. Dukare, A. S.; Paul, S.; Nambi, V. E.; Gupta, R. K.; Singh, R.; Sharma, K.; Vishwakarma, R. K. Exploitation of microbial antagonists for the control of postharvest diseases of fruits: a review. Critical Reviews in Food Science and Nutrition, Philadelphia, v.59, p.1498-1513, 2019.

9. El-Tarabily, K. A. Suppression of Rhizoctonia solani diseases of sugar beet 
by antagonistic and plant growth-promoting yeasts. Journal of Applied Microbiology, Oxford, v. 96, n. 1, p. 69-75, 2004.

10. Ferraz, L. P.; Da Cunha, T.; Da Silva, A. C.; Kupper, K. C. Biocontrol ability and putative mode of action of yeasts against Geotrichum citri-aurantii in citrus fruit. Microbiological Research, Jena, v. 188-189, p. 72-79, 2016.

11. Johnson, L. Iron and siderophores in fungal-host interactions. Mycological Research, Cambridge, v. 112, n. 2, p. 170-183, 2008.

12. Klein, M. N.; Kupper, K. C. Biofilm production by Aureobasidium pullulans improves biocontrol against sour rot in citrus. Food Microbiology, London, v. 69, p.1-10, 2018 .

13. Liu, C. L.; Lan, C. Y.; Fu, C. C.; Juang, R. S. Production of hexaoligochitin from colloidal chitin using a chitinase from Aeromonas schubertii. International Journal of Biological Macromolecules, Amsterdam, v. 69, p. 59-63, 2014.

14. Liu, G. L.; Chi, Z.; Wang, Z. Y.; Wang, Z. P.; Li, Y.; Chi, Z. M. Yeast killer toxins, molecular mechanisms of their action and their applications. Critical Reviews in Biotechnology, London, v. 35, n. 2, p. 222-234, 2015.

15. Magliani, W.; Conti, S.; Gerloni, M.; Bertolotti, D.; Polonelli, L. Yeast killer systems. Clinical Microbiology Reviews, Washington, v. 10, n. 3 , p. 369-400, 1997.

16. Nally, M. C.; Pesce, V. M.; Maturano, Y. P.; Rodriguez Assaf, L. A.; Toro, M. E.; Castellanos de Figueroa, L. I.; Vasquez, F. Antifungal modes of action of Saccharomyces and other biocontrol yeasts against fungi isolated from sour and grey rots. International Journal of Food Microbiology, Amsterdam, v. 204, p. 91-100, 2015.

17. Nunes, C. A. Biological control of postharvest diseases of fruit. European Journal of Plant Pathology, Dordrecht, v. 133, n. 1, p. 181-196, 2012.

18. Ostry, V. Alternaria mycotoxins: an overview of chemical characterization, producers, toxicity, analysis and occurrence in foodstuffs. World Mycotoxin Journal, Bilthoven, v. 1, n. 2, p. 175-188, 2008.

19. Parafati, L.; Vitale, A.; Restuccia, C.; Cirvilleri, G. Biocontrol ability and action mechanism of food-isolated yeast strains against Botrytis cinerea causing post-harvest bunch rot of table grape. Food Microbiology, London, v. 47 , p. 85-92, 2015.

20. Prendes, L. P.; Merín, M. G.; Fontana, A. R.; Bottini, R. A.; Ramirez, M. L.; De Ambrosini, V. I. M. Isolation, identification and selection of antagonistic yeast against Alternaria alternata infection and tenuazonic acid production in wine grapes from Argentina. International Journal of Food Microbiology, Amsterdam, v. 266, p. 14-20, 2018.
21. Rosa, M. M.; Tauk-Tornisielo, S. M.; Rampazzo, P. E.; Ceccato-Antonini, S. R. Evaluation of the biological control by the yeast Torulaspora globosa against Colletotrichum sublineolum in sorghum. World Journal of Microbiology and Biotechnology, Berlim, v. 26, n. 8, p. 1491-1502, 2010.

22. Scarcella, A. S. A.; Bizarria Junior, R., Bastos, R. G.; Magri, M. M. R. Temperature, $\mathrm{pH}$ and carbon source affect drastically indole acetic acid production of plant growth promoting yeasts. Brazilian Journal of Chemical Engineering, São Paulo, v. 34, n. 2, p. 429-438, 2017.

23. Spadaro, D.; Droby, S. Development of biocontrol products for postharvest diseases of fruit: the importance of elucidating the mechanisms of action of yeast antagonists. Trends in Food Science \& Technology, Cambridge, v. 47, p. 39-49, 2016.

24. Thomma, B. P. H. J. Alternaria spp.: from general saprophyte to specific parasite. Molecular Plant Pathology, Oxford, v. 4, n. 4, p. 225-236, 2003

25. Toffano, L.; Fialho, M. B.; Pascholati, S. F. Potential of fumigation of orange fruits with volatile organic compounds produced by Saccharomyces cerevisiae to control citrus black spot disease at postharvest. Biological Control, Atlanta, v. 108, p. 77-82, 2017.

26. Vero, S.; Garmendia, G.; González, M.B.; Bentancur, O.; Wisniewski, M. Evaluation of yeasts obtained from Antarctic soil samples as biocontrol agents for the management of postharvest diseases of apple (Malus $\mathrm{x}$ domestica). FEMS yeast research, Amsterdam, v. 13, n. 2, p. 189-199, 2013.

27. Wezel, A.; Casagrande, M.; Celette, F.; Vian, J.F.; Ferrer, A.; Peigné, J. Agroecological practices for sustainable agriculture. A review. Agronomy for Sustainable Development, Paris, v. 34, n. 1, p. 1-20, 2014.

28. Wicklow, D. T. Interference competition. In: Carrol, G. C.; Wicklow, D. T. The fungal community: its organization and role in the ecosystem. 2nd. New York: Marcel Dekker, 1992. v. 9, chapter 15, p. 265-274.

29. Zhang, D.; Spadaro, D.; Garibaldi, A.; Gullino, M.L. Potential biocontrol activity of a strain of Pichia guilliermondii against grey mold of apples and its possible modes of action. Biological Control, Atlanta, v. 57, n. 3, p. 193-201, 2011.

20. Zhao, Y.; Tu, K. 1.; Shao, X. F.; Jing, W.; Yang, J. L.; Su, Z. P. Biological control of the post-harvest pathogens Alternaria solani, Rhizopus stolonifer, and Botrytis cinerea on tomato fruit by Pichia guilliermondii. The Journal of Horticultural Science and Biotechnology, Ashford, v. 83, n. 1, p. 132-136, 2008. 